Carcass conformation is not very favourable but is better when becoming more compact as ${ }^{-}$the carcass weight increases. Kid carcasses are characterized by a low proportion of fat and by a high muscle/carcass ratio. Proportions of different tissues of shoulder ("épaule") or leg ("gigot") are good predictors of fat, muscle and bone proportions of the carcass. However, mesenteric ("toilette") fat and feet are also good predictors for carcass fat and for carcass muscle and bone, respectively.

In a taste panel of heavy kids (7-I $3 \mathrm{~kg}$ of carcass), genəral opinion was rather favourable $16 \%$ of slightly or very unfavourable opinions on chops, $9 \%$ on shoulder).

In France, heavier kid carcass production might be considered in the future.

\title{
Variations in the adipose tissue composition of prime kids
}

\author{
D. SAUVANT and P. M. FEHR \\ Laboratoive de liecherches de la Chaive de Zootechnie (I.N.R.A.), \\ Institut National Agronomique Paris-Grignon, \\ I6, nue Claude-Bemard, 7.523I Paris Cedex 0.5.
}

Thirty-three male Alpine kids were allotted to three groups and received three different levels of milk replacer. Three kids in each group were slaughtered before weaning, and 8 kids at about $27 \mathrm{~kg}$ of liveweight. The quantity of milk consumed had little effect on fatty acid composition of unweaned kid adipose tissue. After weaning, mesenteric ("toilette"), pericardiac and perirenal fat became particularly rich in stearic acid. The percentage of minor acids (branched and odd-carbon acids) of subcutaneous fat increased. Our results give two indexes on weaned kids which are, respectively, an estimate of the proportion of saturated fatty acids (stearic acid especially in internal fat) and of minor acids in subcutaneous fat. The he-goat origin affected these indexes significantly. Moreover, high intake of milk replacer increased the proportion of minor acids in subcutaneous fat.

\section{Fattening prime kids with an automatic milk feeder}

\author{
M. de SIMIANE $\left({ }^{*}\right)$ and H. MIOSSEC $(* *)$ \\ (*) I.T.O.V.I.C., 149 me de Bercy, 75579 Paris Cedex I2. \\ (**) U.N.I.C.O.P.A., Kergonan, 56440 Languidic.
}

For the last few years, French goat breeders have been using automatic milk feeders to raise prime billy kids up to $24 \mathrm{lbs}$. liveweight. The following results concern 37 Alpine billy kids which first sucked colostrum from a self-feeder for 6 or 7 days. With no transition at all, the animals were put into one group sucking from automatic feeders ( 2 rows of 4 teats) where they received a milk substitute containing $\mathrm{I} 60 \mathrm{~g}$ dry matter per litre.

All the kids were slaughtered very close to liveweight in two groups after $I 7$ and 23 days of automatic feeding. Dressing results were $65 \%$ and $69 \%$, respectively (carcass with head). Daily growth rate average of $250 \mathrm{~g}$ per day was similar for both lots, and $\mathrm{I} .3 \mathrm{~kg}$ of dry milk replacer was used for I $\mathrm{kg}$ of growth. 